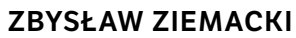

Uczelnia Łazarskiego

ORCID: 0000-0002-3710-5872

Zziemacki@gmail.com

\section{Europejski Zielony Ład i odbudowa polskiej gospodarki -szansei wyzwania}

The European Green Deal and the recovery of the Polish economy - opportunities and challenges

Słowa kluczowe:

polityka klimatyczna, neutralność klimatyczna, Europejski Zielony Ład, zmiany klimatyczne, transformacja energetyczna, ozE, Komisja Europejska, Unia Europejska, fundusze europejskie
Keywords:

climate policy. climateneutral economy, European Green Deal, climate changes, energy transformation, RES, European Commission, European Union, European funds 


\section{The European Green Deal and the recovery of the Polish economy - opportunities and challenges}

Man-made climate change has become the greatest political and economic challenge today. The dictate of GDP as the main measure of prosperity and economic success has led to the wasteful use of natural resources and a drastic increase in greenhouse gas emissions. The consequences are more and more felt: water, food and air pollution, the spread of infectious diseases such as Covid19, or extreme weather phenomena caused by global warming. Limiting these phenomena requires strong and consistent political decisions as well as real actions. The ambitious goals of decarbonisation and climate neutrality adopted by the European Union meet with the strongest resistance and criticism in the former Eastern Bloc countries, whose economies are highly dependent on coal. European policymakers are trying to reconcile the interests of European economies, highly diversified both in terms of the economic structure and the share of fossil fuels in the energy mix. The main tool is to be the unprecedented scale of the European budget earmarked for pro-climate actions, which is to help achieve climate neutrality while maintaining economic growth. 


\section{Wstęp}

7 ainicjowany w 2019 r. Europejski Zielony Ład (EZŁ) to najambitniejsza Linicjatywa w historii Unii Europejskiej, zarówno pod względem gospodarczym, politycznym, jak i społecznym. Zakłada on transformację wszystkich sektorów gospodarki, zwłaszcza energii, rolnictwa, transportu, budownictwa oraz takich gałęzi przemysłu jak przemysł stalowy, cementowy, teleinformatyczny, tekstylny czy chemiczny. Dzięki realizacji ambitnych celów Unia Europejska do roku 2050 stanie się neutralna klimatycznie i zredukuje do zera emisyjność gazów cieplarnianych. Największym jednak problemem jest duże zróżnicowanie strukturalne krajów członkowskich. W szczególności dla krajów postsocjalistycznych, w których przez dziesięciolecia dominowała centralnie planowana gospodarka socjalistyczna oparta na wysokoemisyjnym przemyśle, droga do neutralności klimatycznej wydaje się długa i wyboista. Warunkiem skutecznej realizacji wizji dekarbonizacji Europy jest zapewnienie sprawiedliwych warunków tej gry. Decydenci zaplanowali wiele instrumentów, dzięki którym transformacja ma przebiegać w sposób sprawiedliwy i niedyskryminujący słabiej rozwiniętych regionów charakteryzujących się znacznie wyższym poziomem emisyjności. Wśród krajów, które mają najwięcej do nadrobienia w tym zakresie, jest oczywiście Polska, dla której przewidziano największe bezprecedensowe wsparcie ze środków unijnych. Pytanie, czy zostaną one efektywnie wykorzystane i czy uda się sprostać ambitnym celom EZŁ, pozostaje na razie otwarte. Wiele wskazuje na to, że to ambitne zadanie, przy proponowanym wsparciu UE jest jednak wykonalne.

\section{Kontekst globalny batalii klimatycznej}

Zmiana klimatu i degradacja środowiska naturalnego to aktualnie najpoważniejsze zagrożenia globalne. W najnowszej edycji Global Risk Report opublikowanej w styczniu 2021 r. przez Światowe Forum Ekonomiczne (World Economic Forum, WEF) aż cztery z pięciu największych i najbardziej prawdopodobnych zagrożeń dotyczyły stanu środowiska naturalnego. Według ekspertów i liderów tego forum zagrożenia o najwyższym prawdopodobieństwie wystąpienia $\mathrm{w}$ ciągu następnych dziesięciu lat to ekstremalne warunki pogodowe, niepowodzenia $\mathrm{w}$ działaniach $\mathrm{w}$ dziedzinie klimatu i szkody w środowisku spowodowane przez człowieka, a także 
cyfrowa koncentracja władzy, nierówność cyfrowa oraz zagrożenia związane z cyberbezpieczeństwem. Wśród zagrożeń o najgorszych potencjalnych skutkach autorzy raportu w pierwszej kolejności wskazują na choroby zakaźne, następnie niepowodzenia w działaniach na rzecz klimatu i inne zagrożenia dla środowiska, a ponadto broń masowego rażenia, kryzysy społeczne, kryzysy zadłużenia i awarie infrastruktury IT $^{1}$. W celu podkreślenia wiarygodności tych danych warto zaznaczyć, że już w 2006 r., we wcześniejszej edycji tego raportu, przestrzegano przed ryzykiem pandemii i związanymi z tym konsekwencjami dla ludności i gospodarki ${ }^{2}$. Skupienie się na wzroście gospodarczym i Produkcie Krajowym Brutto (PKB) jako głównych wyznacznikach sukcesów gospodarczych doprowadziło do usilnego dążenia do wzrostu gigantycznej nadprodukcji i rabunkowej gospodarki zasobami naturalnymi. Zrównoważony wzrost gospodarczy oznacza równowagę w wymiarze ekonomicznym, społecznym oraz ekologicznym. Obecny model rozwoju gospodarczego prowadzi do znacznego zaburzenia tej równowagi zarówno w wymiarze ekologicznym, jak i społecznym. Cytując ekspertów Organizacji Współpracy Gospodarczej i Rozwoju (OECD), autorów raportu Poza PKB, „gospodarka, której wzrost nie jest zrównoważony we wszystkich swoich wymiarach (ekonomicznym, społecznym i ekologicznym), okrada przyszłe pokolenia" ${ }^{\prime 3}$. Twarde dane potwierdzają tę tezę. W ostatnim stuleciu światowe zużycie paliw kopalnych i zasobów naturalnych wzrosło dziesięciokrotnie. Według szacunków Międzynarodowej Agencji Energetycznej w 2021 r. spodziewany jest rekordowy wzrost emisji $\mathrm{CO}_{2}$ o prawie $5 \%$, do 33 mld ton. Główną siłą napędową tego wzrostu ma być zwiększenie zapotrzebowania na węgiel, głównie na rynkach wschodzących i w gospodarkach rozwijających się ${ }^{4}$. Od początku lat 7o. ludzkość zużywa więcej zasobów naturalnych niż Ziemia jest w stanie odtworzyć.

1 The global risks report 2021, World Economic Forum 2021 [online, dostęp: 15 V 2021]: 〈https://www.weforum.org/reports/the-global-risks-report-2021〉.

2 The global risks report 2006, World Economic Forum 2006 [online, dostęp: 15 V 2021]: 〈http://www3.weforum.org/docs/WEF_Global_Risks_Report_2006.pdf〉.

3 J. E. Stiglitz, J. P. Fitoussi, M. Durand, Poza PKB. Mierzmy to co ma znaczenie dla rozwoju społeczno-gospodarczego, przeł. Z. Matkowski, Polskie Towarzystwo Ekonomiczne, Warszawa 2019, s. 36: 〈http://www.pte.pl/pliki/pdf/oecd-pl-www.pdf> [dostęp: 15 V 2021].

4 Global carbon dioxide emissions are set for their second-biggest increase in history, IEA [online], 20 IV 2021 [dostęp: 16 V 2021]: 〈https://www.iea.org/news/global-carbon-dioxide-emissions-are-set-for-their-second-biggest-increase-in-history $>$. 
Według obliczeń organizacji Global Footprint Network w 2020 r. dzień długu ekologicznego, czyli dzień, w którym zapotrzebowanie i zużycie surowców naturalnych przekracza zdolność ich dostarczenia lub odtworzenia w ciągu roku przez Ziemię, przypadł 22 sierpnia, a w roku 2019, przed pandemią, gdy światowa gospodarka funkcjonowała na pełnych obrotach, data ta wypadała prawie miesiąc wcześniej. Dla porównania w roku 2000 był to dopiero 23 września, a w 2030 r. prawdopodobnie już od końca czerwca ludzkość będzie żyła na ekologiczny kredyt, który będą musiały spłacać przyszłe pokolenia ${ }^{5}$.

Dynamiczny wzrostu światowej produkcji i konsumpcji doprowadził do wzrostu temperatury na świecie o 1 stopień Celsjusza w porównaniu z okresem przedindustrialnym. Konsekwencje wzrostu są wyraźnie odczuwalne $\mathrm{w}$ postaci ekstremalnych zjawisk pogodowych, zanieczyszczenia wody, żywności, powietrza, rozprzestrzeniania się chorób zakaźnych takich jak COVID-19. Szacunki dalszego wzrostu temperatury przy braku odpowiednich działań ograniczających redukcję emisji $\mathrm{CO}_{2}$ oscylują między 3 a nawet 8 stopni Celsjusza do roku 210o. Według prognoz Komisji Europejskiej do 2100 r. roczne szkody spowodowane wylewaniem rzek w Europie mogą wzrosnąć z 5 mld do 112 mld euro, a 16\% obecnej strefy klimatu śródziemnomorskiego może ulec wyjałowieniu. Jeśli globalna temperatura wzrośnie o $2^{\circ} \mathrm{C}$ zamiast o $1,5^{\circ} \mathrm{C}$, dużo szybciej zacznie brakować żywności ${ }^{6}$.

Wobec coraz większej liczby dowodów empirycznych i naukowych potwierdzających stan zagrożenia klimatycznego głosy sceptyków stały się mniej słyszalne w debacie publicznej. Stany Zjednoczone po objęciu prezydentury przez Joe Bidena ponownie przystąpiły do paryskiego porozumienia klimatycznego, a priorytetem dla Chin, największego na świecie emitenta gazów cieplarnianych, staje się rozwój zielonej gospodarki. Społeczeństwo również jest coraz bardziej świadome zagrożeń dla klimatu

5100 days of possibility, Earth Overshoot Day [online, dostęp: 15 V 2021]: <http:// www.overshootday.org/?__hstc $=104736159.5$ bo1d $606810634 \mathrm{f} 231 \mathrm{fd} 808 \mathrm{~d} 9067$ 69d3.1621265299528.1621861276066.1622293441459.3\&__hssc $=104736159.2 .1622293$ 441459\&__hsfp=161290791>.

6 Neutralność klimatyczna do 2050 r., Strategiczna długoterminowa wizja zamożnej, nowoczesnej, konkurencyjnej $i$ neutralnej dla klimatu gospodarki UE, Komisja Europejska, Bruksela 2019, s. 5: <https://op.europa.eu/pl/publication-detail/-/ publication/92f6d5bc-76bc-11e9-9fo5-01aa75ed71a1 > [dostęp: $16 \mathrm{~V} 2021$ ]. 
i środowiska. Według badania Eurobarometru z 2020 r. 94\% obywateli we wszystkich państwach członkowskich UE twierdzi, że ochrona środowiska jest dla nich ważna. Ponadto $91 \%$ obywateli stwierdziło, że zmiany klimatyczne są poważnym problemem w UE. Według $83 \%$ ankietowanych europejskie prawodawstwo jest niezbędne do ochrony środowiska ${ }^{7}$.

Mimo powszechnej świadomości tego zagrożenia, zarówno wśród rządzących, jak i wśród obywateli, w ślad za deklaracjami składanymi na forach światowych nie szły jednak żadne konkretne działania. W zawartym w $2015 \mathrm{r}$. porozumieniu paryskim określono ogólnoświatowy plan działania, którego celem jest zapobieganie zmianom klimatu i ograniczenie globalnego ocieplenia do wartości poniżej $2^{\circ} \mathrm{C}$ w porównaniu z epoką przedprzemysłową. Kraje członkowskie UE nie wykazywały wystarczającej aktywności w realizacji tych postanowień, w żadnym kraju nie powstały szczegółowe strategie dotyczące implementacji postanowień paryskich. W związku z tym Komisja Europejska w grudniu 2019 r. przedstawiła nową koncepcję zrównoważonego rozwoju dla Unii Europejskiej Nowy Zielony Ład.

\section{Zielony Ład - europejskie remedium na wyzwania klimatyczne}

Inicjatywa Komisji dotycząca Zielonego Ładu ma zintensyfikować działania na rzecz klimatu oraz przyspieszyć wdrażanie odpowiednich strategii i prawodawstwa we wszystkich krajach członkowskich UE. Strategia NZŁ odpowiada na główne wyzwania i problemy związane $\mathrm{z}$ aktualnym stanem środowiska naturalnego i klimatu. Głównym jej celem jest przekształcenie UE w sprawiedliwe i prosperujące społeczeństwo żyjące w nowoczesnej, zasobooszczędnej i konkurencyjnej gospodarce, która w 2050 r. osiąǵnie zerowy poziom emisji gazów cieplarnianych netto i w ramach której wzrost gospodarczy będzie oddzielony od wykorzystania zasobów naturalnych. Oprócz wymiaru środowiskowego strategia kładzie duży nacisk na kwestie społeczne. Jej celem jest również ochrona, zachowanie i poprawa kapitału

7 New Eurobarometer survey: Protecting the environment and climate is important for over 90\% of European citizens, European Comission, Brussels [online], 3 III 2020 [dostęp: 16 V 2021]: <https://ec.europa.eu/commission/presscorner/detail/en/ IP_20_331>. 
naturalnego UE oraz ochrona zdrowia i dobrostanu obywateli przed zagrożeniami i negatywnymi skutkami związanymi ze środowiskiem ${ }^{8}$.

Europejski Zielony Ład to najambitniejsza inicjatywa w historii Unii Europejskiej zarówno pod względem gospodarczym, politycznym, jak i społecznym.

Wizja Komisji Europejskiej kreśli siedem głównych elementów strategicznych związanych z przechodzeniem do zeroemisyjnej gospodarki. Są to:

1) maksymalizacja efektywności energetycznej, w tym budynki o zerowej emisji;

2) maksymalizacja wykorzystania odnawialnych źródeł energii (OzE) oraz elektryczności do pełnej dekarbonizacji dostaw energii w Europie;

3) przyjęcie zasad czystej, bezpiecznej i połączonej mobilności;

4) konkurencyjny przemysł UE i gospodarka obiegu zamkniętego jako kluczowe czynniki redukcji emisji gazów cieplarnianych;

5) rozwój odpowiedniej inteligentnej infrastruktury sieciowej i wzajemnych połączeń;

6) pełne wykorzystanie zalet biogospodarki i stworzenie niezbędnych pochłaniaczy dwutlenku węgla;

7) rozwiązanie problemu pozostałych emisji $\mathrm{CO}_{2}$ za pomocą wychwytywania i składowania dwutlenku węgla (cCs) ${ }^{9}$.

Przestawienie europejskiej gospodarki na zielone tory wymaga rozbudowania zaawansowanego systemu finansowania i odpowiedniego pakietu legislacyjnego, który wdroży postanowienia w życie. Według szacunków Komisji Europejskiej w samej Europie osiągnięcie nowego celu redukcji emisji do $2030 \mathrm{r}$. będzie wymagało corocznie dodatkowych inwestycji w wysokości ok. 350 mld euro ${ }^{10}$.

Oprócz nakładów finansowych konieczne są również odważne i nie zawsze powszechnie akceptowane decyzje polityczne. Za głównego sprawcę emisji gazów cieplarnianych uważa się węgiel brunatny i kamienny. Według obliczeń noblisty z ekonomii, Williama Nordhausa, węgiel powoduje

8 Communication from the Commission, The European Green Deal, European Commission, Brussels [online], 11 XII 2019 [dostęp: 16 V 2021]: 〈https://ec.europa.eu/ info/files/annex-roadmap-and-key-actions_en>.

9 Neutralność klimatyczna do 2050 r., Strategiczna długoterminowa wizja...

10 A Global Green Deal: op-ed by von der Leyen and Hoyer (EIB), Komisja Europejska [online], 22 III 2021 [dostęp: 16 V 2021]: <https://ec.europa.eu/commission/ presscorner/detail/en/AC_21_1322>. 
sześciokrotnie większą emisję $\mathrm{CO}_{2} \mathrm{w}$ przeliczeniu na koszt jednostkowy. Według tych szacunków ropa naftowa o wartości 1000 USD emituje 0,9 ton $\mathrm{CO}_{2}$, gaz ziemny 2 tony $\mathrm{CO}_{2}$ na 1000 USD paliwa, natomiast węgiel emituje aż 11 ton $\mathrm{CO}_{2}$ na 1000 USD paliwa ${ }^{11}$.

\section{Dysproporcje strukturalne gospodarek i regionów UE}

Zamykanie elektrowni węglowych i ograniczanie spalania węgla jest najbardziej efektywnym sposobem dekarbonizacji. Dużym wyzwaniem politycznym jest jednak wysokie uzależnienie poszczególnych gospodarek od sektora węglowego i związana z tym perspektywa likwidacji wielu miejsc pracy. Według raportu Komisji Europejskiej z 2018 r., który analizuje szanse i wyzwania dla europejskich regionów węglowych, w 2018 r. na terenie Unii Europejskiej w sektorze węglowym zatrudnionych było 237 tys. osób, z czego 185 tys. w górnictwie. Największy udział w tej liczbie, ok. 50\% zatrudnionych, przypada Polsce, następne są: Niemcy, Czechy, Rumunia, Bułgaria, Grecja i Hiszpania. Dwadzieścia regionów europejskich zapewnia prawie 200 tys. miejsc pracy bezpośrednio związanych z węglem, z czego sześć znajduje się w Polsce. Według tych samych analiz w samym województwie śląskim w 2018 r. w sektorze węglowym zatrudnionych było 82,5 tys. osób. Autorzy raportu szacują, że ograniczenie emisji $\mathrm{CO}_{2}$ do roku 2030 o 40\% w stosunku do 1990 r. pociągnie za sobą redukcję 160 tys. osób zatrudnionych bezpośrednio w branży węglowej. Tylko na Śląsku z powodu transformacji energetycznej do 2030 r. pracę może stracić 41 tys. osób ${ }^{12}$. Należy podkreślić, że szacunki te dotyczą planów $40 \%$ redukcji emisji $\mathrm{CO}_{2}$ do $2030 \mathrm{r}$. w stosunku do roku 1990, natomiast już wiadomo, że wskaźnik ten zostanie zwiększony do $55 \%$ $\mathrm{w}$ wyniku implementacji w najbliższym czasie prawa klimatycznego UE.

W związku z tym droga to neutralności klimatycznej dla Polski, ale też innych krajów ze wschodniej Europy z wysokim udziałem przemysłu węglowego w gospodarce, takich jak Bułgaria, Rumunia, Czechy czy

11 W. Nordhaus, Kasyno klimatyczne. Ryzyko, niepewność i ekonomia globalnego ocieplenia, przeł. Z. Matkowski, Polskie Towarzystwo Ekonomiczne, Warszawa 2021, s. 187.

12 EU coal regions: opportunities and challenges ahead, European Commission, Joint Research Centre, Bruksela 2018, s. 2-3: 〈https://publications.jrc.ec.europa.eu/repository/bitstream/JRC112593/kjna29292enn.pdf> [dostęp: 16 V 2021]. 
Słowacja, będzie znacznie trudniejsza w porównaniu z większością krajów bogatszego unijnego Zachodu.

Odsetek zatrudnionych w sektorze wydobycia paliw kopalnych

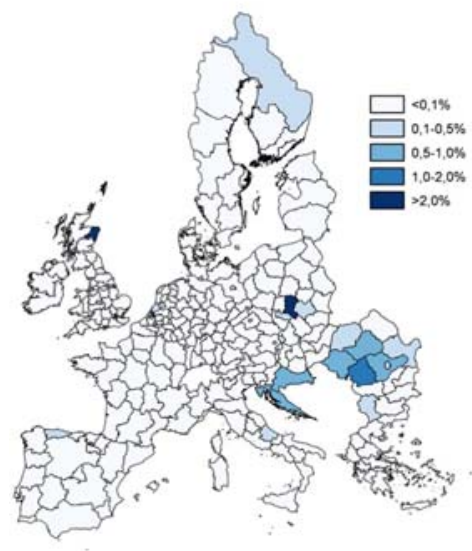

Odsetek zatrudnionych w sektorach energochlonnych i przemyśle motoryzacyjnym

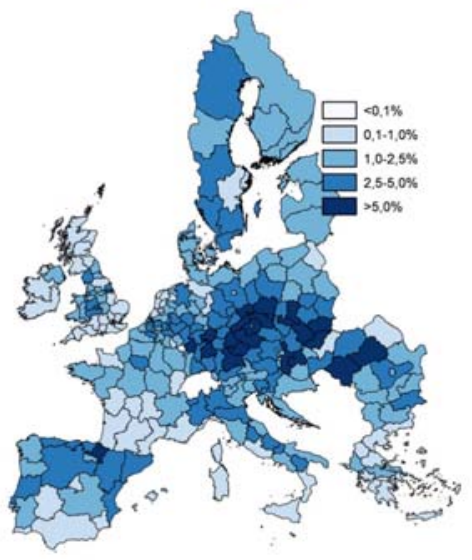

Mapa 1. Zatrudnienie na poziomie regionalnym w sektorach wydobycia paliw kopalnych i sektorach energochłonnych (poziom NUTS2)

Źródło: Czysta planeta dla wszystkich, Europejska długoterminowa wizja strategiczna dobrze prosperującej, nowoczesnej, konkurencyjnej ineutralnej dla klimatu gospodarki, Komunikat Komisji, Komisja Europejska [online], 28 XI 2018 [dostęp:19 V 2021]: <https://eur-lex.europa.eu/ legal-content/PL/TXT/HTML/?uri=CELEX:52018DC0773\&from=EN>.

\section{Łagodny scenariusz transformacji w górnictwie}

Warto podkreślić, że wiele zmian strukturalnych w branży górniczej ma stosunkowo łagodny przebieg i wynika w dużej mierze z naturalnych zmian demograficznych. Eksperci Instytutu Badań Strukturalnych w raporcie Dekarbonizacja i zatrudnienie $w$ górnictwie węgla kamiennego $w$ Polsce szacują, że „od początku transformacji górnictwa w latach 90-tych XX wieku do końca 2019 r. zatrudnienie w górnictwie zmniejszyło się o około 300 tys. miejsc pracy (spadek o 76\%), zamknięto ponad 40 kopalń, a wydobycie spadło o ponad $90 \mathrm{mln}$ ton (zmiana o 58\%)". Raport IBS wśród bezpośrednich przyczyn tego zjawiska po stronie popytowej wymienia: „spadek energochłonności PKB, spadek zapotrzebowania na węgiel, rozwój technologii produkcji energii na rzecz innych źródeł, sytuacja na międzynarodowym rynku węgla, zaostrzanie norm środowiskowych związanych z emisją $\mathrm{CO}_{2}$ oraz wzrost cen uprawnień do emisji"; natomiast po stronie podażowej: 
„pogarszające się warunki eksploatacji złóż i wysokie koszty udostępniania nowych zasobów oraz wysoki udział kosztów stałych w strukturze kosztów produkcji węgla"13.

Biorąc pod uwagę powyższe, u podstaw redukcji zatrudnienia w górnictwie leżą głównie procesy rynkowe. W dużej mierze redukcja zatrudnienia była i jest oparta na naturalnym procesie przechodzenia kolejnych roczników na emerytury oraz innych łagodnych instrumentach, takich jak: świadczenia pieniężne (odprawy i zasiłki), instrumenty aktywizujące (szkolenia, stypendia, kontrakty na przekwalifikowanie, wsparcie podejmowania działalności gospodarczej) oraz instrumenty skierowane do pracodawców (refundacje składek, zwrot kosztów zatrudnienia). Równolegle ograniczano napływ nowych pracowników do branży.

Równocześnie wiele analiz wskazuje na pozytywny wpływ zielonej transformacji na rynek pracy. Według danych Komisji Europejskiej w roku 2018 w UE było około 4 mln tzw. zielonych miejsc pracy, a wdrażanie unijnych celów energetycznych na rok 2020 przyczyniło się do wzrostu zatrudnienia w UE o $1-1,5 \%{ }^{14}$. Inwestycje uruchamiane $w$ ramach zielonej transformacji europejskiej gospodarki powinny zniwelować z nawiązką redukcję zatrudnienia w branżach węglowych. Modernizacja przemysłu, transformacja energetyczna, gospodarka o obiegu zamkniętym, czysta mobilność wygeneruje wiele nowych i atrakcyjniejszych miejsc pracy. Z kolei według założeń Polityki energetycznej Polski do 2040 r. transformacja wygeneruje do 300 tys. nowych miejsc pracy w branżach o wysokim potencjale, w szczególności związanym z OZE, energetyką jądrową, elektromobilnością, infrastrukturą sieciową, cyfryzacją oraz termomodernizacją budynków ${ }^{15}$. Wydaje się, że liczba ta jest niedoszacowana i nie uwzględnia miejsc pracy pośrednio związanych $\mathrm{z}$ transformacją energetyczną oraz skali finansowania zewnętrznego $\mathrm{w}$ obszarze zielonych technologii.

13 Dekarbonizacja i zatrudnienie w górnictwie wegla kamiennego w Polsce, Instytut Badań Strukturalnych, 2021, s. 6-7: <https://ibs.org.pl/app/uploads/2021/o1/IBSResearch-Report-01-2021.pdf> [dostęp: $17 \mathrm{~V}$ 2021].

14 Neutralność klimatyczna do 2050 r., Strategiczna długoterminowa wizja...

15 Polityka energetyczna Polski do 2040 r. przyjęta przez Radę Ministrów, Ministerstwo Klimatu i Środowiska [online], 2 II 2021 [dostęp: 17 V 2021]: <https://www.gov.pl/web/ klimat/polityka-energetyczna-polski-do-2040-r-przyjeta-przez-rade-ministrow $\rangle$. 


\section{Dodatkowe obciążenia dla wysoko emisyjnych gospodarek}

Skutkiem ubocznym zwiększenia celów ograniczania emisji $\mathrm{CO}_{2}$ z 40 do $55 \%$ jest gualtowny wzrost kosztów uprawnień do emisji $\mathrm{CO}_{2}$. Między listopadem 2020 a lutym 2021 r. ceny uprawnień wzrosły o $70 \%{ }^{16}$. Podwyżki te dotykają zwłaszcza kraje o najwyższej intensywności emisji $\mathrm{CO}_{2} \mathrm{w}$ energetyce, a Polska pod tym względem jest niechlubnym liderem. To kolejny argument na rzecz pilnej intensyfikacji działań dekarbonizacyjnych.

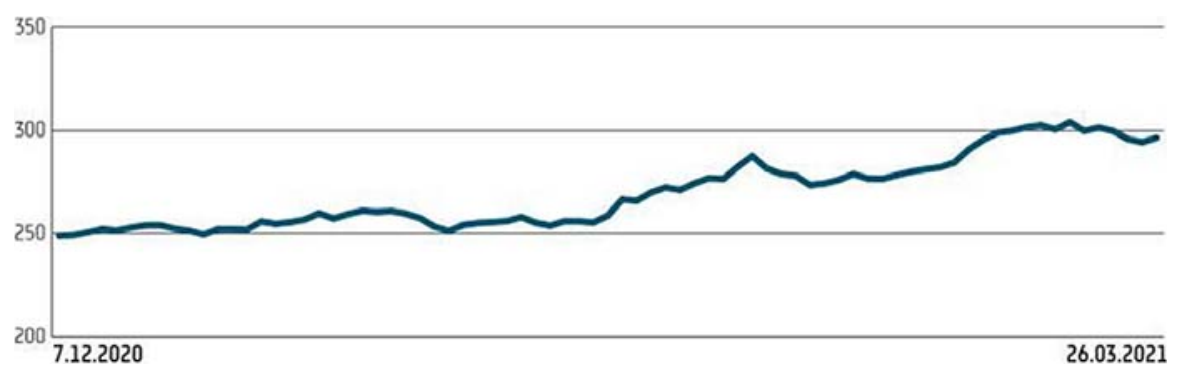

Wykres 1. Hurtowe ceny energii z dostaw na przyszły rok w Polsce (zł/MWH)

Źródło: Najczarniejzzy sen wytwórców energiijuzis sięspetnia, „Parkiet” [online], 29 III 2021 [dostęp: 17 V 2021]: <https://www.parkiet.com/ Energetyka/303299983-Najczarniejszy-sen-wytworcow-energii-juz-sie-spelnia.html>.

\section{Sprawiedliwa transformacja}

To, jak osiągnąć zerową emisyjność i nie pogrążyć w kryzysie gospodarek i regionów najbardziej uzależnionych od paliw kopalnych, stanowi duże wyzwanie dla unijnych przywódców. Nie uda się to bez odpowiednich zachęt i wsparcia finansowego dla regionów najbardziej dotkniętych negatywnymi społeczno-gospodarczymi skutkami transformacji. W tym celu Komisja Europejska stworzyła mechanizm sprawiedliwej transformacji, który według założeń ,jest kluczowym narzędziem służącym zapewnieniu, by transformacja na rzecz gospodarki neutralnej dla klimatu przebiegała $\mathrm{w}$ sposób sprawiedliwy, nie pozostawiając nikogo samemu

16 Najczarniejszy sen wytwórców energii już się spetnia, „Parkiet” [online], 29 III 2021 [dostęp: 17 V 2021]: 〈https://www.parkiet.com/Energetyka/303299983Najczarniejszy-sen-wytworcow-energii-juz-sie-spelnia.html〉. 


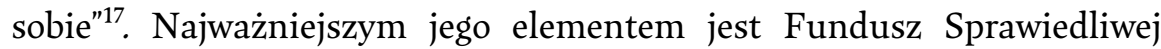
Transformacji (FST) przeznaczony na tworzenie miejsc pracy, nowe inwestycje, walkę ze smogiem, rekultywację terenów pokopalnianych, szkolenia i kursy dla pracowników i osób bezrobotnych. Według wstępnych założeń na FST planowano przeznaczyć 40 mld euro, ostatecznie kwotę tę zredukowano do 17,5 mld euro. 7,5 mld euro w FST pochodzi z wieloletnich ram finansowych (WRF), a 10 mld euro - z funduszu Next Generation EU.Zakłada się, że łącznie z pozostałymi dwoma filarami (InvesteU oraz wparciem Europejskiego Banku Inwestycyjnego) mechanizm w połączeniu z wkładem prywatnym uruchomi ok. 100 mld euro na wsparcie sprawiedliwiej transformacji.

\section{Wyzwania polityczne}

Pierwsze poważne problemy polityczne na drodze do neutralności klimatycznej, wynikające ze zróżnicowanej struktury energetycznej krajów członkowskich, pojawiły się już na starcie. Podczas szczytu UE w 2019 r. jedynym krajem, który nie zgodził się na podjęcie zobowiązania osiągnięcia neutralności klimatycznej do 2050 r. była Polska. Przedstawiciele polskiego rządu argumentowali swoją decyzję brakiem precyzyjnych zapisów dotyczących mechanizmów finansowania transformacji. Ponadto strona polska domagała się wprowadzenia zapisu o przyjęciu celu zerowej emisyjności netto na poziomie całej UE, a nie poszczególnych krajów. Aby wybrnąć z politycznego impasu, na żądanie Polski w porozumieniu klimatycznym z 2019 r. wprowadzono zapis mówiący o tym, że na tym etapie jedno państwo członkowskie nie może zobowiązać się do realizacji tego celu .

Brak deklaracji neutralności klimatycznej oznacza dla Polski poważne konsekwencje finansowe. Polska ma być największym beneficjentem wspomnianego wcześniej Funduszu Sprawiedliwej Transformacji. Dla polskich gmin przewidziano $20 \%$ wszystkich środków, tj. 3,5 mld euro. Ale zgodnie z zasadami FST warunkiem otrzymania pełnej kwoty jest zobowiązanie się do realizacji celów klimatycznych. Dopóki Polska nie zmieni zdania i nie zobowiąże się do wdrożenia celu neutralności klimatycznej do $2050 \mathrm{r}$.,

17 Mechanizm sprawiedliwej transformacji: $z$ myśla o wszystkich, Komisja Europejska [online, dostęp: $17 \mathrm{~V}$ 2021]: <https://ec.europa.eu/info/strategy/priorities-2019-2024/ european-green-deal/actions-being-taken-eu/just-transition-mechanism_pl $>$. 
połowa tej kwoty będzie zamrożona. Wydaje się jednak, że taka decyzja polskich władz była bardziej zabiegiem populistycznym wynikającym z kalendarza wyborczego niż długofalową strategią. Dalszy opór w tym zakresie oprócz potencjalnych strat finansowych może nie przynieść wymiernych korzyści. W przeciwieństwie do reguł szczytów UE do przyjęcia poszczególnych przepisów w ramach Zielonego Ładu nie jest wymagana jednomyślność, a jedynie większość głosów europosłów oraz unijnych ministrów w Radzie UE. Zatem samotny opór Polski w tym obszarze niewiele może zmienić. Poparcie społeczne to również istotny czynnik, który rządzący muszą brać pod uwagę przy podejmowaniu takich decyzji. Według badań Kantara w 2019 r. aż 81\% badanych Polaków deklarowało poparcie Zielonego Ładu dla Europy, a tylko 10\% było przeciwnych. Jednocześnie 69\% ankietowanych popierało cel osiągnięcia neutralności klimatycznej do 2050 r. i było przeciwnych nieprzyjęciu podjęcia takiego zobowiązania przez polski rząd. Dodatkowo należy podkreślić, że zobowiązanie do zerowej emisyjności ma charakter deklaratywny i długofalowy, a unijne prawo nie precyzuje konsekwencji wynikających z braku osiągnięcia celów emisyjności do 2050 r. Natomiast w krótszym okresie naraża nasz kraj na utratę prawie 2 mld euro z Funduszu Sprawiedliwej Transformacji, nie wspominając o stratach politycznych i wizerunkowych.

Wiele wskazuje na to, że polski rząd jest coraz bliżej decyzji o deklaracji neutralności klimatycznej. W kwietniu 2021 r. negocjatorzy Parlamentu Europejskiego i unijnych krajów zawarli wstępne porozumienie w sprawie pakietu klimatycznego zwane prawem klimatycznym UE. Przed ostatecznym przyjęciem prawo to musi zostać zatwierdzone przez Radę Europejską oraz Parlament Europejski. Rada zatwierdziła porozumienie w maju $2021 \mathrm{r}$.

Najważniejszym elementem porozumienia jest zaostrzenie celu ograniczenia unijnych emisji $\mathrm{CO}_{2} \mathrm{z} 40 \%$ do $55 \%$ do 2030 r. (w porównaniu z wielkością emisji netto z roku 1990). Tym razem udało się spełnić postulat Polski i wprowadzić do porozumienia zapis mówiący o tym, że cel ten zostanie osiągnięty kolektywnie, w wyniku kontrybucji krajów członkowskich przy uwzględnieniu specyficznych uwarunkowań krajowych oraz sytuacji wyjściowej. Strona polska nie negowała zapisów prawa klimatycznego. Należy jednak zauważyć, że przyjęcie roku 1990 za rok bazowy emisji $\mathrm{CO}_{2}$ jest w przypadku Polski pewnym ułatwieniem ze wzğlędu na efekt wysokiej bazy. Do $1990 \mathrm{r}$. centralnie sterowana polska gospodarka była w większości oparta na przemyśle, charakteryzując się bardzo wysoką emisyjnością. Po 1990 r. w wyniku 
transformacji znaczna część aktywności gospodarczej przesunęła się z sektora przemysłu do sektora usług. Według danych z raportu firmy McKinsey pt. Neutralna emisyjnie Polska $2050^{18}$ dzięki zwiększeniu efektywności energetycznej przemysłu, obniżeniu zużycia węgla kamiennego i brunatnego oraz zwiększeniu udziału energii pochodzącej ze źródeł odnawialnych emisja gazów cieplarnianych w Polsce zmalała z $447 \mathrm{MtCO}_{2}$ e (megaton ekwiwalentu dwutlenku węgla) w 1990 r. do $380 \mathrm{MtCO}_{2}$ e w 2017 r.

\section{Dobre wyniki Polski w dekarbonizacji}

Z kolei według danych Eurostatu dotyczących emisji $\mathrm{CO}_{2}$ w 2019 r. polskie osiągnięcia w ograniczaniu emisji $\mathrm{CO} 2$ były lepsze niż średnia Unii Europejskiej. W porównaniu do roku 2018 emisja $\mathrm{CO}_{2} \mathrm{w}$ Polsce zmalała o 5,7\%, natomiast średni spadek dla całej Unii wyniósł 4,3\%. Gorsze wyniki niż Polska odnotowały m.in. Niemcy $(-4,6 \%)$, Czechy $(-2,2 \%)$ czy Węgry $(-1,5 \%)$. Największy spadek emisji $\mathrm{CO} 2$ odnotowano w Estonii $(-22,1 \%)$, a największy wzrost w Luksemburgu $(+7,5 \%)^{19}$.

Mimo tych optymistycznych danych Polska w dalszym ciągu jest niechlubnym liderem pod względem intensywności emisji $\mathrm{CO}_{2} \mathrm{w}$ energetyce. W związku z tym koszty energii w naszym kraju są bardzo wrażliwe na wahania cen uprawnień do emisji $\mathrm{CO}_{2}$. Zwiększenie wymaganych poziomów ograniczania emisji $\mathrm{CO}_{2} \mathrm{z} 40$ do $55 \%$ spowodowało dynamiczny wzrost kosztów tych uprawnień, co w najbliższym czasie przełoży się na podwyżki cen energii i spowoduje większą presję inflacyjną.

Aby zminimalizować negatywne efekty gospodarcze wzrostu cen uprawnień emisji $\mathrm{CO}_{2}$, należy zintensyfikować transformację energetyczną. $\mathrm{Z}$ tej perspektywy wskaźniki określone w ramach polityki energetycznej, takiej jak: co najmniej $23 \%$ OZE w końcowym zużyciu energii brutto w $2030 \mathrm{r}$.

18 H. Engel, M. Purta, E. Speelman, G. Szarek, P. van der Pluijm, Neutralna emisyjnie Polska 2050, Jak wyzwanie zmienić w szansę, McKinsey \& Company 2020, s. 6: <https:// www.mckinsey.com/pl/ /media/mckinsey/locations/europe $\% 20$ and $\% 20$ middle $\% 20$ east/polska/raporty/carbon\%20neutral\%20poland $\% 202050 /$ neutralna $\% 20 e m i s y j-$ nie\%20polska\%202050_raport\%20mckinsey.pdf> [dostęp: $19 \mathrm{~V}$ 2021].

19 In 2019, $\mathrm{CO} 2$ emissions from energy use in the EU estimated to have decreased, Eurostat [online], $6 \mathrm{~V} 2020$ [dostęp: $17 \mathrm{~V} \mathrm{2021]:<https://ec.europa.eu/euro-}$ stat/documents/2995521/10820684/8-06052020-BP-EN.pdf/e1dd6cf1-09b5-d7eeb769-ffe63e94561e>. 
oraz ograniczenie emisji GHG o 30\% do 2030 r. (w stosunku do 1990 r.) są mało ambitne i niewystarczające.

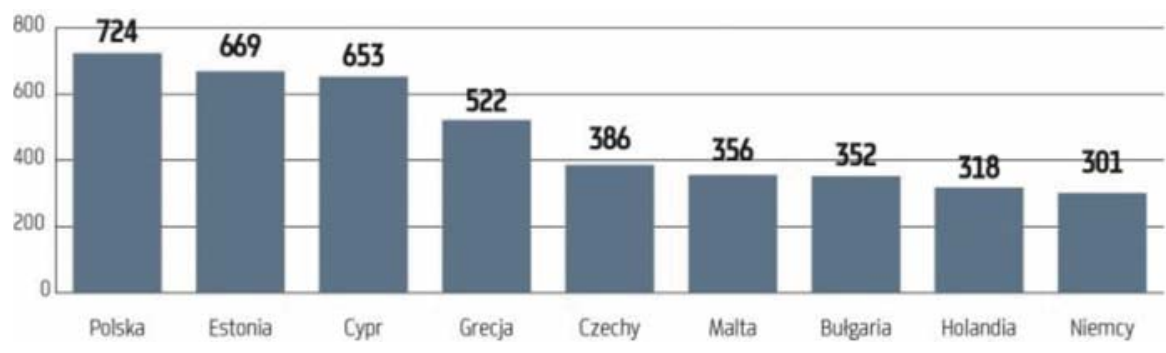

Wykres 3. Kraje o najwyższej intensywności emisji $\mathrm{CO}_{2} \mathbf{w}$ energetyce

Źródło: Najczarniejszy sen wytwórców energii już się spełnia, „Parkiet” [online], 29 III 2021 [dostęp: 17 V 2021]: <https://www.parkiet.com/

Energetyka/303299983-Najczarniejszy-sen-wytworcow-energii-juz-sie-spelnia.html>.

Koszty i możliwości finansowania transformacji

W grudniu 2019 r., podczas prezentacji założeń Nowego Zielonego Ładu, przewodnicząca Ursula von der Leyen powiedziała: „Europejski Zielony Ład jest naszą nową strategią na rzecz wzrostu - wzrostu, którego korzyści są większe niż koszty" ${ }^{20}$. Czy będzie to również polski scenariusz, zależy $\mathrm{w}$ dużej mierze od odpowiednich decyzji politycznych oraz efektywnego wykorzystana unijnego budżetu.

Według analiz Komisji Europejskiej zerowa emisyjność wymaga zwiększenia inwestycji $\mathrm{w}$ system energetyczny i związaną $\mathrm{z}$ nim infrastrukturę z ok. 2\% PKB UE do 2,8\% rocznie (tj. ok. 520-575 mld euro). Oznacza to konieczność zwiększenia inwestycji na poziome całej Unii o 175 do 290 mld euro rocznie. Jednocześnie analiza przewiduje oszczędności na poziomie 200 mld euro rocznie w systemy ochrony zdrowia wynikające z poprawy jakości powietrza i co za tym idzie - zdrowia obywateli UE. Prognozy te są zbliżone do szacunków Międzyrządowego Zespołu ds. Klimatu (IPCC) dotyczących zmiany temperatury o $1,5^{\circ} \mathrm{C}$ w latach

20 Europejski Zielony Ład: jak do 2050 r. uczynić z Europy pierwszy neutralny dla klimatu kontynent, stymulując gospodarkę, poprawiając stan zdrowia i jakość życia obywateli, dbając o przyrodę $i$ nie pozostawiając $w$ tyle żadnej osoby ani żadnego regionu, Komunikat prasowy, Komisja Europejska [online], 11 XII 2019 [dostęp: 17 V 2021]: 〈https://ec.europa.eu/commission/presscorner/detail/pl/IP_19_6691〉. 
2016-2035, według których niezbędne są inwestycje w system energetyczny na poziomie ok. $2,5 \%$ globalnego $\mathrm{PKB}^{21}$.

Badacze analizujący na poziomie krajowym zakładają mniejszy udział koniecznych inwestycji w stosunku do PKB. Według szacunków ekspertów firmy McKinsey, aby osiągnąć neutralność klimatyczną, Polska musiałaby czterokrotnie przyspieszyć dekarbonizację w porównaniu z tempemem działań w poprzednich trzydziestu latach. Koszty dodatkowych inwestycji umożliwiających odpowiednią redukcję emisji gazów cieplarnianych w ciągu kolejnych trzydziestu lat powinny wynieść ok. 10-13 mld euro rocznie lub 1-2\% PKB. Według autorów raportu wizja osiągnięcia neutralności klimatycznej w Polsce, zgodnie z założeniami EZŁ, do roku 2050 jest realna. Omawiany w raporcie scenariusz zakłada, że do 2050 r. Polska jest w stanie obniżyć poziom emisji gazów cieplarnianych względem 2017 r. o 91\%, głównie poprzez zwiększenie: wykorzystania odnawialnych źródeł energii oraz pochłaniania dwutlenku. które zrekompensuje pozostałe $9 \%$ emisji ${ }^{22}$.

Trochę mniej optymistycznie wyglądają obliczenia zawarte w strategicznym dokumencie rządowym, jakim jest Polityka Energetyczna Polski do roku 2040 (PEP 2040). Według tych szacunków wysokość wydatków inwestycyjnych związanych $\mathrm{z}$ transformacją energetyczną w latach 2021-2040 może sięgnąć ok. 1600 mld PLN, W tym ok. 867-890 mld PLN na inwestycje w sektorach paliwowo-energetycznych oraz ok. 320-342 mld PLN na inwestycje w sektorze wytwórczym energii elektrycznej, z czego ok. 80\% zostanie przeznaczone na moce bezemisyjne, tj. OzE i energetykę jądrową ${ }^{23}$. Jest to ambitne zadanie, wymagające wysokich nakładów finansowych, te jednak w dużej części mogą zostać pokryte ze środków Unii Europejskiej.

Według zapisów PEP2O4O na krajową transformację energetyczno-klimatyczną do 2030 r. skierowanych zostanie ok. 260 mld PLN ze środków unijnych i krajowych w ramach różnych mechanizmów, m.in.:

21 Czysta planeta dla wszystkich, Europejska długoterminowa wizja strategiczna dobrze prosperującej, nowoczesnej, konkurencyjnej i neutralnej dla klimatu gospodarki, Komunikat Komisji, Komisja Europejska [online], 28 XI 2018 [dostęp: 19 V 2021]: <https://eur-lex.europa.eu/legal-content/PL/TXT/HTML/?uri=CELEX:52018DCO773 \&from $=\mathrm{EN}>$.

22 H. Engel, M. Purta, E. Speelman, G. Szarek, P. van der Pluijm, Neutralna emisyjnie Polska 2050.

23 Polityka energetyczna Polski do 2040 r. 
1) Polityki Spójności - ok. 79 mld PLN;

2) Instrumentu na rzecz Odbudowy i Zwiększania Odporności ok. 97,8 mld PLN;

3) Funduszu na rzecz Sprawiedliwej Transformacji - ok. 15,6 mld PLN;

4) ReactEU - ok. 1,8 mld PLN;

5) pozostałych instrumentów (np. programy priorytetowe NFOŚiGW oraz środki Wspólnej Polityki Rolnej) - ok. 20 mld PLN;

6) nowych instrumentów, które będą wspierać transformację systemu energetycznego w Polsce, np. Funduszu Modernizacyjnego oraz krajowego funduszu celowego, zasilanego środkami ze sprzedaży uprawnień do emisji $\mathrm{CO}_{2}$, tj. Funduszu Transformacji Energetyki, ok. 47,6 mld PLN.

Dlatego na tym etapie kluczowym pytaniem, jakie należy sobie postawić, nie jest czy, tylko jak dążyć do osiągnięcia neutralności klimatycznej. Jak maksymalizować szanse i minimalizować zagrożenia związane z transformacją gospodarczą zgodną z postulatami Nowego Zielonego Ładu.

\section{Tabela 1. Wieloletnie ramy finansowe 2021-2027 całkowite przydziały środków według działu*}

\begin{tabular}{|c|c|c|c|}
\hline Dział & WRF & NextGenerationEU & RAZEM \\
\hline $\begin{array}{l}\text { 1. Jednolity rynek, innowacje } \\
\text { i technologie cyfrowe }\end{array}$ & 132,8 mld EUR & 10,6 mld EUR & 143,4 mld EUR \\
\hline 2. Spójność, odporność i wartości & 377,8 mld EUR & 721,9 mld EUR & 1099,7 mld EUR \\
\hline 3. Zasoby naturalne i środowisko & 356,4 mld EUR & 17,5 mld EUR & 373,9 mld EUR \\
\hline 4. Migracja i zarządzanie granicami & 22,7 mld EUR & - & $22,7 \mathrm{mld}$ EUR \\
\hline 5. Bezpieczeństwo i obrona & 13,2 mld EUR & - & 13,2 mld EUR \\
\hline 6. Kraje sąsiadujące i reszta świata & 98,4 mld EUR & - & 98,4 mld EUR \\
\hline 7. Europejska administracja publiczna & $73,1 \mathrm{mld}$ EUR & - & 73,1 mld EUR \\
\hline Ogółem & 1074,3 mld EUR & 750 mld EUR & $1824,3 \mathrm{mld}$ EUR \\
\hline
\end{tabular}

Budżet UE na lata 2021-2027 wyniesie ponad 1,8 bln euro. $\mathrm{Z}$ tej kwoty 750 mld euro przeznaczono na tymczasowy instrument odbudowy gospodarczej Next Generation EU, który ma pomóc naprawić bezpośrednie szkody gospodarcze i społeczne spowodowane pandemią CoviD-19 ${ }^{24}$.

24 Plan odbudowy dla Europy, Komisja Europejska [online, dostęp: 27 V 2020]: $\langle$ https://ec.europa.eu/info/strategy/recovery-plan-europe_pl>. 
$37 \%$ środków z tego instrumentu ma zostać przeznaczonych na cele środowiskowe, a $20 \%$ na cele związane $\mathrm{z}$ transformację cyfrową. Dzięki temu, zgodnie z założeniami, Europa po pandemii CovID-19 stanie się bardziej przyjazna dla środowiska, bardziej cyfrowa, odporniejsza i lepiej przygotowana na obecne i przyszłe wyzwania. Łącznie na cele klimatyczne ma zostać wydatkowane 30\% całego budżetu UE na lata 2021-2027, czyli prawie 550 mld euro.

Aż 173 mld euro z unijnego budżetu na lata 2021-2027 trafi do Polski, w tym 139 mld euro $w$ formie dotacji, reszta jako niskooprocentowane pożyczki. Podobnie jak w przypadku całego budżetu UE, również 30\% polskiej alokacji powinno zostać przeznaczone na cele klimatyczne, czyli ponad 57 mld euro. Fundusze te mogą stać się istotną siłą napędową odbudowy gospodarki po pandemii na nowych zielonych i zrównoważonych zasadach.

Czy uda się pogodzić wychodzenie z głębokiego kryzysu z przestawianiem gospodarki na zielone tory? To zadanie trudne, ale nie niemożliwe, wymaga jednak odpowiednich działań i determinacji zarówno ze strony rządzących, jak i interesariuszy, którzy będą wdrażać ambitne i trudne projekty.

\section{Krajowy Plan Odbudowy - papierek lakmusowy polskich reform}

Pierwszym sprawdzianem jest Krajowy Plan Odbudowy (KPO), jego opracowanie i akceptacja przez Komisję Europejską jest podstawą do uzyskania pieniędzy z Instrumentu na Rzecz Odbudowy i Zwiększania Odporności (RRF). Z tej puli Polska będzie miała do dyspozycji 23,9 mld euro w formie grantów oraz 34,2 mld euro $\mathrm{w}$ formie pożyczek. $\mathrm{Z}$ ogólnej puli środków $20 \%$ musi trafić na cyfryzację, a $37 \%$ na inwestycje związane ze środowiskiem oraz ochroną zdrowia.

W przesłanym do Komisji Europejskiej na początku maja dokumencie przedstawiono plan finansowania realizacji celów przyjętych w KPO. Do sierpnia 2026 r. zaplanowano wydatkowanie całej dostępnej dla Polski w ramach RRF sumy środków bezzwrotnych w wysokości 23,9 mld euro oraz 12112 mld euro z części pożyczkowej RRF.Z tej puli najwięcej, bo ponad 14 mld euro, przewidziano na realizację celów dotyczących zielonej energiii zmniejszania energochłonności. 


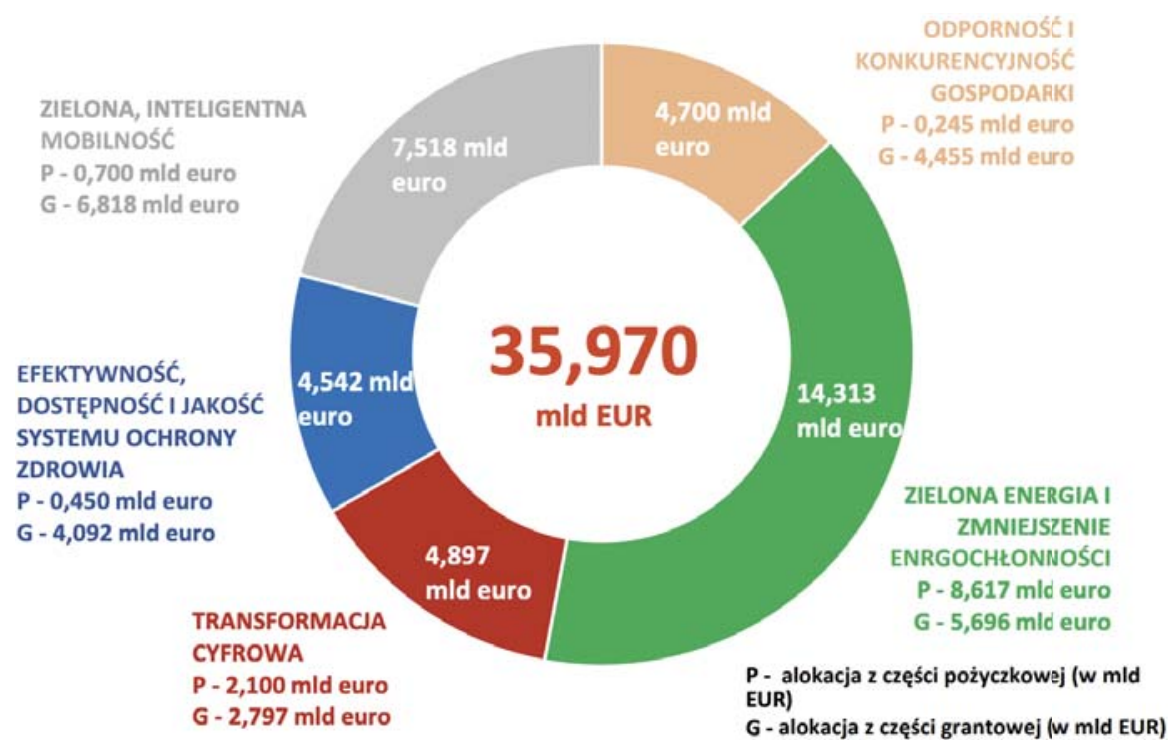

Wykres 4. Podział środków w ramach KPO

Źródło: KPO wysłany do Komisji Europejskiej, Serwis Rzeczypospolitej Polskiej [online], 3 V 2021 [dostęp: 27 V 2020]: shttps://www.gov.pl/web/ planodbudowy/kpo-wyslany-do-komisji-europejskiej>.

Pierwotnie przesłany do KE dokument miał sporo merytorycznych mankamentów, był wewnętrznie niespójny, stanowił kompilację chaotycznie posklejanych fragmentów różnego rodzaju dokumentów rządowych, a przedstawione $\mathrm{w}$ nim cele nie odzwierciedlały wyzwań wynikających z unijnych ambicji transformacyjnych. Część tych mankamentów można uzasadnić dużym tempem prac nad dokumentem. Ministerstwo Funduszy i Polityki Regionalnej, odpowiedzialne za przygotowanie dokumentu w trakcie konsultacji społecznych, otrzymało ponad 5 tys. uwag oraz komentarzy i propozycji do Krajowego Planu Odbudowy.

W drodze merytorycznych konsultacji z KE udało się zniwelować te braki, jednak na drodze do akceptacji KPO i wypłaty Polsce pierwszych środków, czyli zaliczki w kwocie 4,7 mld euro, stanęły kwestie polityczno-prawne. Komisja Europejska postawiła Polsce trzy warunki, tj:: zobowiązanie się do likwidacji Izby Dyscyplinarnej Sądu Najwyższego, zakończenie lub reforma systemu dyscyplinowania sędziów oraz rozpoczęcie przywracania usuniętych sędziów.

Trwający spór oznacza kolejne miesiące bez pieniędzy dla polskich przedsiębiorców i samorządów na tak bardzo potrzebne Polsce inwestycje 
wspierające zrównoważony rozwój i łagodzące skutki kryzysu wywołanego pandemią. Nawet w przypadku optymistycznego scenariusza i szybkiego porozumienia z KE kwestie proceduralne, takie jak konieczność wydania ostatecznej decyzji przez unijną radę ministrów, powodują, że Polska może liczyć na pierwsze środki w ramach KPO nie wcześniej niż w czerwcu 2022 roku.

\section{Zakończenie}

Głównym środkiem ciężkości polityki klimatycznej Unii Europejskiej i Europejskiego Zielonego Ładu jest transformacja energetyczna. Biorąc pod uwagę światową sytuację klimatyczną i wyczerpywanie się surowców naturalnych, im szybciej polska gospodarka uniezależni się od paliw kopalnych, tym lepiej. Bezprecedensowa skala możliwego dofinansowania ze środków UE na lata 2021-2027 w znacznym stopniu ułatwi proces przechodzenia do niskoemisyjnej gospodarki. Odwlekanie jednak transformacji w czasie narazi polską gospodarkę na wysokie koszty opłat za emisję $\mathrm{CO}_{2}$, utratę części dofinansowania z Unii, dodatkowe koszty ponoszone na utrzymywanie nierentownych kopalń oraz straty wizerunkowe i polityczne. Ponadto większy udział OzE w miksie energetycznym Ppolski oznacza większą niezależność energetyczną dzięki redukcji importu paliw kopalnych.

Istotne są też względy zdrowotne, transformacja energetyczna to lepsze powietrze, lepszy klimat i zdrowsze społeczeństwo, a w konsekwencji znaczne oszczędności wydatków na służbę zdrowia.

Kolejne decyzje na szczeblu unijnym przyspieszają proces przechodzenia do zeroemisyjnej gospodarki. Negowanie tych postanowień niewiele zmieni, ponieważ w przypadku Nowego Zielonego Ładu prawo weta nie obowiązuje. Dlatego wszystkie wysiłki rządzących powinny koncentrować się na maksymalizacji efektywności wykorzystania środków na realizację zielonej, opartej na innowacjach transformacji. O ile do tej pory Polska radziła sobie całkiem dobrze $\mathrm{z}$ wydawaniem unijnych funduszy, to efektywność ich wydatkowania, m.in. na wsparcie polskich innowacji była stosunkowo niewielka. Często pokutowało przekonanie, że pieniądze z UE to darmowy kapitał, który wystarczy „wpompować” do polskiej gospodarki, a za największy sukces często uważa się zamknięcie i rozliczenie projektu. Liczne badania ewaluacyjne dotyczące realizacji dotychczasowych polityk wsparcia rozwoju gospodarki ze środków UE dostarczają bogatej wiedzy i informacji na temat działań pożądanych i niepożądanych. Obecnie 
kluczowe pytania to: na ile rządzący wykorzystają tę wiedzę i dotychczasowe doświadczenia oraz kiedy uda się przełamać polityczny impas dotyczący reformy sądownictwa.

\section{Bibliografia}

100 days of possibility, Earth Overshoot Day [online, dostęp: 15 V 2021]: <http:// www.overshootday.org/?__hstc=104736159.5bo1d606810634f231fd8o8d9067 69d3.1621265299528.1621861276066.1622293441459.3\&__hssc $=104736159.2 .162$ 2293441459\&__hsfp $=161290791>$.

A Global Green Deal: op-ed article by Ursula von der Leyen, President of the European Commission, and Werner Hoyer, President of the European Investment Bank, Komisja Europejska [online], 22 III 2021 [dostęp: 16 V 2021]: <https://ec.europa. $\mathrm{eu} /$ commission/presscorner/detail/en/AC_21_1322>.

Communication from the Commission, The European Green Deal, European Commission, Brussels [online], 11 XII 2019 [dostęp: 16 V 2021]: 〈https:// ec.europa.eu/info/files/annex-roadmap-and-key-actions_en>.

Czysta planeta dla wszystkich, Europejska dlugoterminowa wizja strategiczna dobrze prosperujacej, nowoczesnej, konkurencyjnej i neutralnej dla klimatu gospodarki, Komunikat Komisji, Komisja Europejska [online], 28 XI 2018 [dostęp: $19 \mathrm{~V}$ 2021]: <https://eur-lex.europa.eu/legal-content/PL/TXT/HTML/?uri=CELEX:52 018DCO 773 \&from $=\mathrm{EN}\rangle$.

Dekarbonizacja $i$ zatrudnienie $w$ górnictwie węgla kamiennego $w$ Polsce, Instytut Badań Strukturalnych, 2021, s. 6-7: <https://ibs.org.pl/app/uploads/2021/o1/ IBS-Research-Report-01-2021.pdf> [dostęp: $17 \mathrm{~V}$ 2021].

Engel H., Purta M., Speelman E., Szarek G., van der Pluijm P., Neutralna emisyjnie Polska 2050, Jak wyzwanie zmienić w szanse, McKinsey \& Company 2020, s. 6: <https://www.mckinsey.com/pl/ /media/mckinsey/locations/europe\%20 and $\% 20$ middle $\% 20$ east $/$ polska/raporty/carbon $\% 2$ neutral\%2opoland $\% 20$ 2050/neutralna\%20emisyjnie\%20polska\%202050_raport\%20mckinsey.pdf> [dostęp: $19 \mathrm{~V}$ 2021].

EU coal regions: opportunities and challenges ahead, European Commission, Joint Research Centre, Bruksela 2018, s. 2-3: <https://publications.jrc.ec.europa.eu/ repository/bitstream/JRC112593/kjna29292enn.pdf> [dostęp: 16 V 2021].

Global carbon dioxide emissions are set for their second-biggest increase in history, IEA [online], 20 IV 2021 [dostęp: 16 V 2021]: 〈https://wwwiea.org/news/global-carbon-dioxide-emissions-are-set-for-their-second-biggest-increase-in-history $\rangle.$ The global risks report 2006, World Economic Forum 2006 [online, dostęp: $15 \mathrm{~V}$ 2021]: 〈http://www3.weforum.org/docs/WEF_Global_Risks_Report_2006.pdf $\rangle$. The global risks report 2021, World Economic Forum 2021 [online, dostęp: $15 \mathrm{~V}$ 2021]: 〈https://www.weforum.org/reports/the-global-risks-report-2021> KPO 
wysłany do Komisji Europejskiej, Serwis Rzeczypospolitej Polskiej [online], 3 V 2021 [dostęp: 27 V 2020]: <https://www.gov.pl/web/planodbudowy/kpowyslany-do-komisji-europejskiej $>$.

Mechanizm sprawiedliwej transformacji: $z$ myśla o wszystkich, Komisja Europejska [online], [dostęp: $17 \mathrm{~V}$ 2021]: <https://ec.europa.eu/info/strategy/ priorities-2019-2024/european-green-deal/actions-being-taken-eu/justtransition-mechanism_pl>.

Najczarniejszy sen wytwórców energiii już się spetnia, "Parkiet” [online], 29 III 2021 [dostęp: 17 V 2021]: <https:/www.parkiet.com/Energetyka/303299983Najczarniejszy-sen-wytworcow-energii-juz-sie-spelnia.html $>$.

Neutralność klimatyczna do 2050 r., Strategiczna długoterminowa wizja zamożnej, nowoczesnej, konkurencyjnej i neutralnej dla klimatu gospodarki UE, Komisja Europejska, Bruksela 2019, s. 5: <https://op.europa.eu/pl/publication-detail/-/ publication/92f6d5bc-76bc-11e9-9fo5-01aa75ed71a1> [dostęp: $16 \mathrm{~V}$ 2021].

New Eurobarometer survey: Protecting the environment and climate is important for over 90\% of European citizens, European Comission, Brussels [online], 3 III 2020 [dostęp: 16 V 2021]: <https://ec.europa.eu/commission/presscorner/detail/ en/IP_20_331>.

Nordhaus W., Kasyno klimatyczne. Ryzyko, niepewność i ekonomia globalnego ocieplenia, przeł. Z. Matkowski, Polskie Towarzystwo Ekonomiczne, Warszawa 2021.

Plan odbudowy dla Europy, Komisja Europejska [online, dostęp: 27 V 2020]: $\langle$ https://ec.europa.eu/info/strategy/recovery-plan-europe_pl>.

Polityka energetyczna Polski do 2040 r. przyjęta przez Radę Ministrów, Ministerstwo Klimatu i Środowiska [online], 2 II 2021 [dostęp: 17 V 2021]: <https://www.gov.pl/web/klimat/polityka-energetyczna-polski-do-2040-rprzyjeta-przez-rade-ministrow $\rangle$.

Stiglitz J. E., Fitoussi J. P., Durand M., Poza РКB. Mierzmy to, co ma znaczenie dla rozwoju społeczno-gospodarczego, przeł. Z. Matkowski, Polskie Towarzystwo Ekonomiczne, Warszawa 2019, s. 36: <http://www.pte.pl/pliki/pdf/oecd-pl-www. pdf> [dostęp: 15 V 2021]. 